\title{
Does the World Need a Universal Financial Institution?
}

James M. Boughton 


\title{
IMF Working Paper
}

Policy Development and Review Department

\section{Does the World Need a Universal Financial Institution?}

\author{
Prepared by James M. Boughton ${ }^{1}$
}

June 2005

\begin{abstract}
This Working Paper should not be reported as representing the views of the IMF. The views expressed in this Working Paper are those of the author(s) and do not necessarily represent those of the IMF or IMF policy. Working Papers describe research in progress by the author(s) and are published to elicit comments and to further debate.

All financial institutions specialize, in dimensions that may include categories of assets and liabilities, types of services offered, customer demographics, and geographic coverage. The International Monetary Fund is the only international financial institution that is universal in its geographic scope, prepared to lend on request to virtually any country in the world. Why has this status come about? What are its costs and benefits? Is it an appropriate model for a world where macroeconomic imbalances, financial crises, and disparities in economic development must compete for attention and resources?
\end{abstract}

JEL Classification Numbers: F33, F34, F42

Keywords: IMF, international financial institutions, low-income countries, emerging markets Author(s) E-Mail Address: jboughton@imf.org

\footnotetext{
${ }^{1}$ Forthcoming in World Economics, Vol. 6, No. 2 (April-June 2005). I am grateful to, but do not wish to implicate, Andy Berg, Scott Brown, Peter Kenen, Tim Lane, Domenico Lombardi, James McEuen, Jeromin Zettelmeyer, and seminar participants at Oxford and Princeton Universities for helpful comments.
} 
Contents

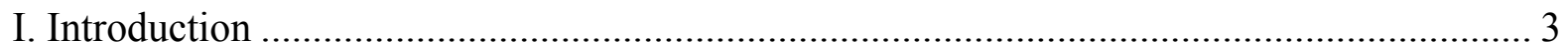

II. The Evolution of the IMF and Its Membership........................................................ 4

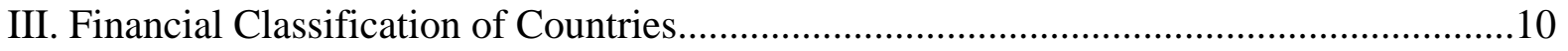

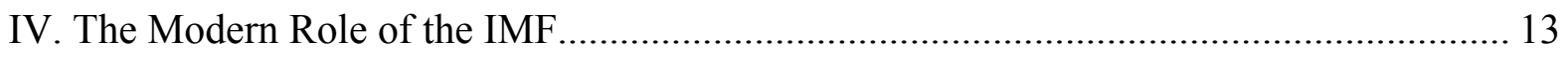

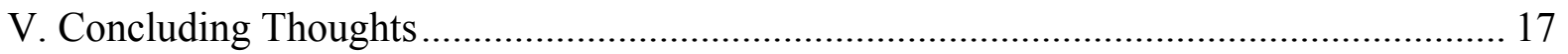

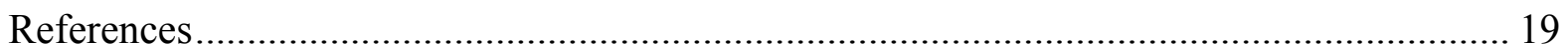

Figures

1. G-7 and Developing Countries: Net Financial Position in the IMF, 1947-2004_.............. 5

2. Selected Countries: Net Financial Position in the IMF, Through 2004 ........................... 7

3. Number of IMF Creditors, 1947-2004 f.................................................................. 11 
"The issue is not whether the Fund should take an interest in poverty, but whether it should continue working, and working better, with its poorest member countries. The answer to that is yes: as a universal institution, we have to stay involved with all our members."

Stanley Fischer (2001)

\section{INTRODUCTION}

When the Soviet Union disintegrated in 1991 and all of the newly emergent countries joined the membership of the International Monetary Fund, the IMF almost overnight became a nearly universal financial institution. Today (in 2005) it has 184 member countries, just 7 fewer than the United Nations. In contrast, Citibank - the most globally engaged private financial institution - is active in about 100 countries. As Stanley Fischer (then the First Deputy Managing Director of the IMF) indicated in his farewell address to the IMF's Executive Board (quoted above), the distinction is not trivial.

Universalism is not only a question of membership. Several official international agencies now have universal, or near-universal, membership, including the United Nations and many of its specialized agencies as well as both the IMF and the World Bank (but not yet the World Trade Organization). ${ }^{2}$ Having a very broad and inclusive membership is obviously a necessary condition, but it is not sufficient. More fundamentally, it is a question of focus. The World Bank lends only to developing and transition countries: to middle-income countries through its original body, the International Bank for Reconstruction and Development (IBRD), and to low-income countries through its concessional-lending arm, the International Development Association (IDA) (see World Bank, 2004). In contrast, any one of the 184 member countries - Uganda or the United States - can borrow from the IMF: the only financial institution in the world with this universal approach to lending.

A broad implication of this fact is that the IMF is designed to function as a cooperative, or a club of peers. In principle, each member country might be a creditor part of the time and a borrower at other times. Since the early years of the IMF (which started

\footnotetext{
${ }^{2}$ Membership in the IMF (184 countries in 2005) is not quite as universal as that of the United Nations (191). Throughout the Cold War, most states with Communist governments elected not to join the IMF. Since 1990, nearly all of those formerly in that category have joined, but neither Cuba nor North Korea has done so. Five tiny countries that are members of the UN also have not applied to join the IMF: three in Europe (Andorra, Liechtenstein, and Monaco) and two in the South Pacific (Nauru and Tuvalu). World Bank membership currently is identical to that of the IMF. The World Trade Organization has 148 members, 36 fewer than the Bank and the Fund, though 27 other countries are in process of accession to membership.
} 
lending in 1947), this revolving-fund aspect has been important. Canada, Denmark, France, Italy, and the United Kingdom are all countries that are now financial and industrial powers but that have in the past cycled between being creditors and debtors of the IMF. Even Japan and the United States had stand-by arrangements with the IMF in the early years. And this distinguishing feature of the Fund has not vanished. More recently, China, the Czech Republic, Estonia, and the Republic of Korea have been borrowers for a time and are now creditors, and Russia is on the threshold of making that transition for the first time. Over the past 25 years (1980-2004), some 44 countries have switched between being net financial contributors to the IMF and being debtors, and back, at least once.

Universal lending by the IMF is an adjunct to the even more comprehensive use of surveillance. The Fund is the only financial institution that conducts routine (usually annual) consultations with all countries. These consultations focus primarily on macroeconomic policies but also cover related structural issues such as the soundness of the financial sector and the country's adherence to a variety of internationally accepted standards and codes. When and if a member country applies to borrow from the Fund, the knowledge that the staff has gained through these consultations, and the policy advice that it has given, make a useful starting point for discussion of lending terms and policy conditions. More generally, the consultations are a platform for the Fund to develop and disseminate a comprehensive and consistent policy framework covering all regions and economies.

\section{THE EVOLUTION OF THE IMF AND ITS MEMBERSHIP}

The predominant perception of the IMF today is rather different from this universal model of uniform treatment of member countries. For the most part, the Fund today is thought to be an institution with a sizeable number of member countries that have had persistent creditor positions for at least the past two decades, an even larger number of members with persistent debtor positions, and a small middle group that might move from one side to the other. The seven largest industrial countries, which constitute themselves as the Group of Seven (G-7) for financial discussions, are often used as a metaphor for the larger group of creditor countries. Hence the popular image of the Fund is illustrated by Figure 1, which shows how a large debit position by developing countries in the aggregate has been financed in large part by the corresponding credit positions of the G-7. While this pattern is evident to some extent in the first half of the chart (1947 through the 1970s), it is especially striking in the more recent period.

The dotted line at +25 percent in Figures 1 and 2 marks the boundary between making a standard financial contribution to the Fund as a condition of membership and being an active creditor. A contribution of approximately 25 percent of quota is the standard quota subscription for each member country. A country with no outstanding net transactions other 
- 5 -

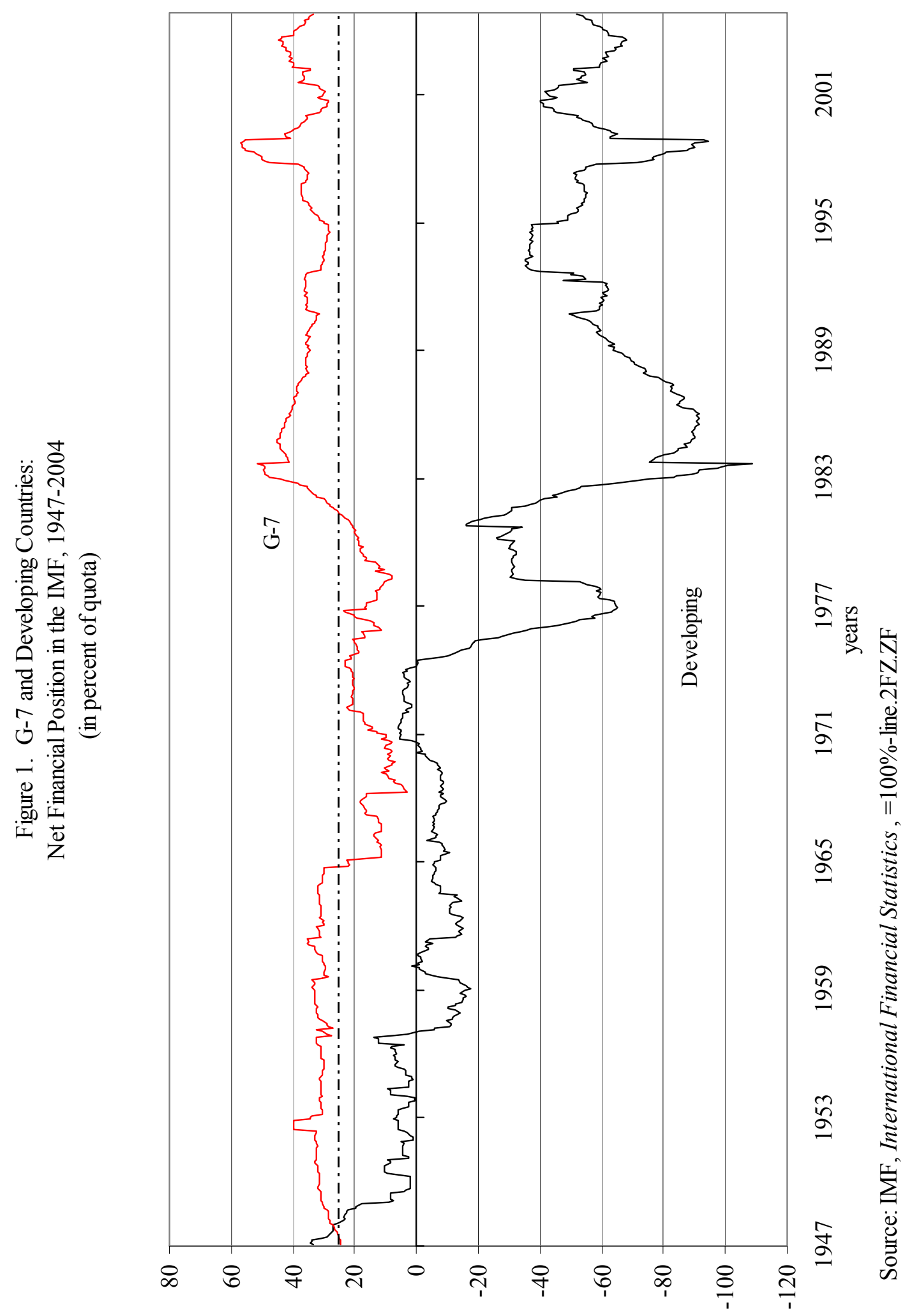


than its subscription will have a net credit position at that level. ${ }^{3}$ As a corollary, a zero position means that the member has withdrawn its own subscription and is neither contributing to the Fund nor borrowing from it. When the IMF lends to a country, it normally uses currencies contributed by members with strong finances and credits those countries with an additional claim. Countries with net claims greater than 25 percent of quota are thereby the creditors of the Fund.

From 1965 through mid-1981, when some G-7 countries had outstanding debts to the Fund, the group's aggregate net creditor position fell below the 25 percent threshold (bottoming out at 3.2 percent in June 1968). For most of the Fund's history, however, the G-7 has had an aggregate creditor position.

The devil being in the details, it is worth taking a closer look at the IMF's financial relations with a few individual countries (Figure 2). The top two panels illustrate how two G-7 countries - the United Kingdom and Italy - had recourse to IMF financing in the past. The United Kingdom had five separate episodes as a debtor - and had a debtor position for more than half of the time-before ascending in 1980 to an apparently permanent position as a financial contributor or creditor. Note, however, that the United Kingdom has had a significant creditor position only in the early 1980s and since 1997. In contrast, Italy has been a creditor for most of its time as an IMF member, but it too borrowed fairly large sums in the 1970s.

Next, as an illustration of how this cycle of fortune is continuing in more recent periods, consider the case of the Republic of Korea (middle left panel). Korea spent its first two decades in the IMF as a contributor, then borrowed heavily for a decade or so. By the end of the 1980s, Korea appeared-like the United Kingdom-to have become a permanent creditor. In an implicit recognition of that new, stronger, status, the OECD accepted Korea as a member in 1996, and the IMF reclassified Korea alongside countries such as Japan as an

${ }^{3}$ The net financial position shown in the diagram is equal to 100 minus the Fund's holdings of the country's currency in percent of quota. When a country joins the Fund, it is assigned a quota based on the size of the economy and its international trade, and it is required to deposit 22.7 percent of its quota in Special Drawing Rights (SDRs) or in strong currencies that the Fund is currently using in lending operations. The balance is credited in the member's own currency. Subscriptions for subsequent increases in quotas are paid 25 percent in strong currencies or SDRs, the balance in the member's currency. Consequently, a country that has had no transactions with the Fund other than its quota subscriptions would have a net creditor position close to 25 percent of quota, but the exact percentage would depend on the length of membership and on how the country's quota has evolved. Here, 25 percent is used uniformly for simplicity. Since 1978, each member has had the right to withdraw all or any part of its hard-currency payment, even permanently, without penalty or cost except for the interest forgone on the balance. 
Figure 2. Selected Countries: Net Financial Position in the IMF, Through 2004 (in percent of quota)

United Kingdom, 1947-2004

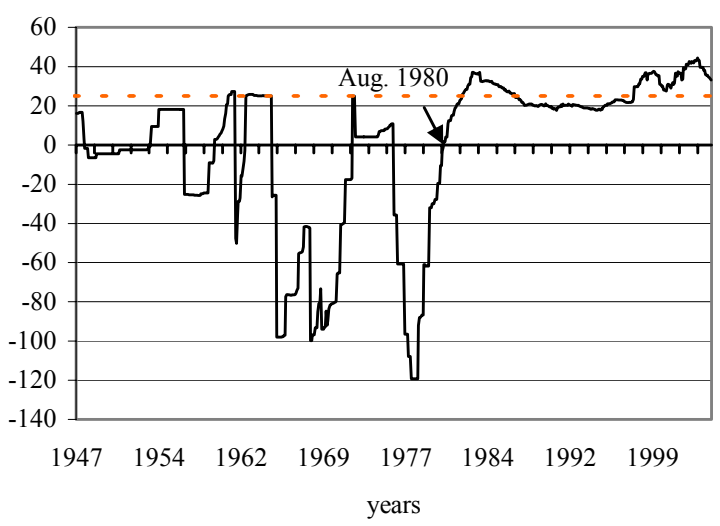

Republic of Korea, 1965-2004

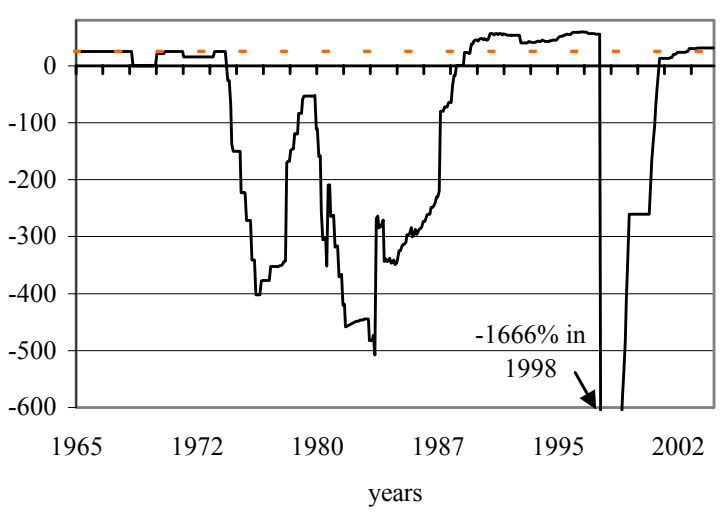

Indonesia, 1954-2004

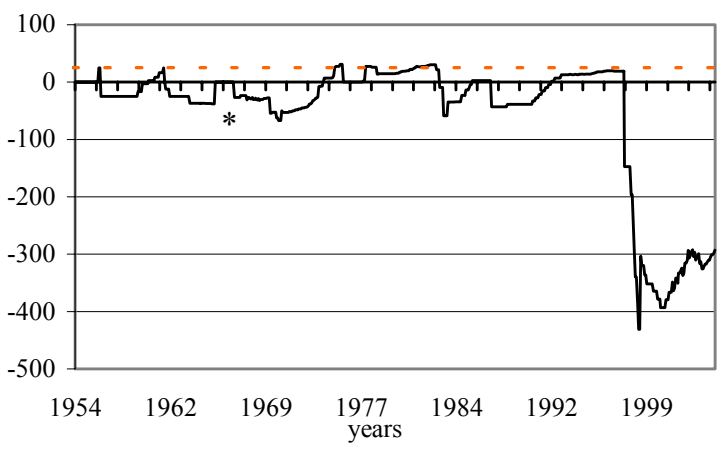

* withdrew from membership, August 1965 to February 1967

Source: See Figure 1.
Italy, 1959-2004

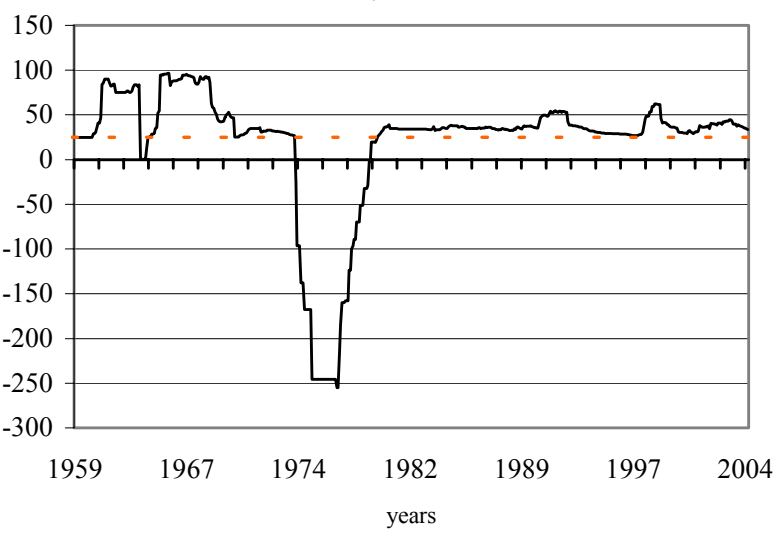

Israel, 1957-2004

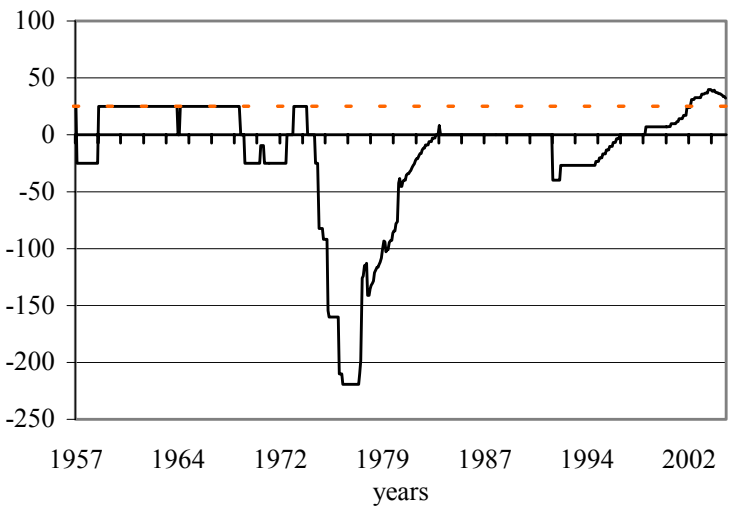

Russian Federation, 1992-2005

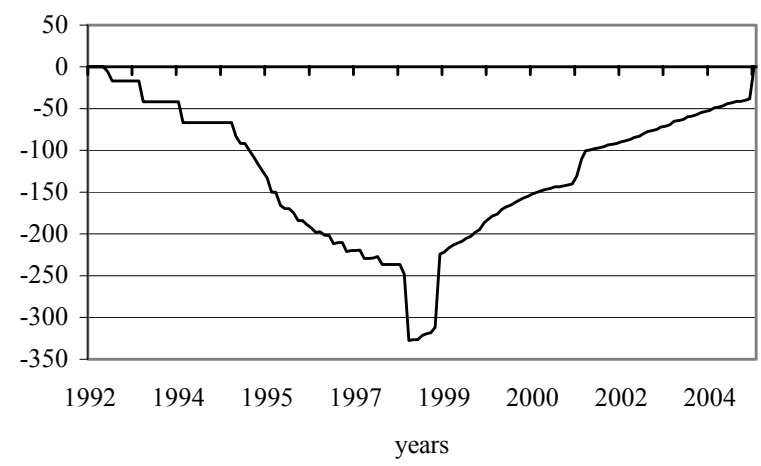


"advanced economy" rather than alongside China and others as a developing country. Then came the financial crisis of 1997, and Korea briefly became the Fund's largest debtor, with a debit position of nearly 17 times its quota in 1998. By 2001, however, Korea had repaid all of its debts to the IMF and had regained its creditor position.

The next two panels of Figure 2 demonstrate that developing countries also may cycle in and out of debtor status as they try to advance economically along a bumpy path. Israel has had four distinct episodes as a debtor and currently has a sizeable creditor position. ${ }^{4}$ Indonesia cycled regularly between debtor and contributor or creditor positions over more than four decades prior to the crisis of 1997-98. Although neither of these examples may be considered typical of the experience of developing countries, neither are they isolated examples. As of 2004, 58 of the 129 members classified as developing countries had a positive financial position in the Fund, and 15 of those were creditors.

To complete the picture, the last panel in Figure 2 shows the brief history of Russia's financial relations with the IMF, starting in 1992 when Russia became a member. As Russia struggled with its initial transition toward establishing a market economy, it borrowed heavily for the first six years and then (following the financial crisis of 1998) began repaying. At the end of January 2005, Russia completed all of its repayments ahead of schedule and brought its debtor position to a close. Several other countries with transition economies have either already become creditors (such as Hungary and Poland) or have at least moved out of negative territory (notably Estonia and Latvia).

Focusing on the aggregate picture rather than on the demands and needs of individual countries can lead one to question the relevance of the universal-institution model and even the very rationale for an institution such as the IMF. High-income countries, as a rule, no longer borrow from the Fund. ${ }^{5}$ Low-income countries do, but what they need most is longterm development aid, not shorter-term stabilization assistance. Middle-income countries usually borrow only in response to a financial crisis, in which case crisis resolution may require sums that are quite large in relation to the IMF's resources. In any case, what middleincome countries would benefit from most - and can usually obtain except during crisis periods - is private rather than official capital.

The logic of this aggregate and static view of the world led the Meltzer Commission to recommend to the U.S. Congress that IMF lending be limited to short-term lending to "solvent emerging economies" (Meltzer, 2000, p. 41), a phrase intended to exclude most low-income countries as well as middle-income countries that are in severe crisis. Countries

\footnotetext{
${ }^{4}$ In 1997, the IMF reclassified Israel from a developing country to an advanced economy.

${ }^{5}$ Aside from Korea, the last stand-by arrangements with industrial countries were in 1977 (Italy and the United Kingdom) and 1978 (Spain). In a few cases in the 1980s, industrial countries did draw on the Fund in other ways: Australia (from the Buffer Stock Financing Facility, in 1982), Iceland (from the Compensatory Financing Facility, also in 1982), and Denmark (a reserve tranche drawing, in 1987).
} 
that lack access to private credit markets and that need long-term financing on concessional terms would, under their proposal, generally be shunted over to the World Bank, regional development banks, and bilateral donors. Similarly, but from a quite different ideological perspective, Oxfam International also has argued for a smaller IMF role in low-income countries, based on an essentially static view of the world. Their 2003 report criticized the IMF for aiming to help poor countries graduate from aid dependency to a more reliable access to private-sector financing. In Oxfam's view, this goal "is simply not realistic for many poor countries" (p. 6) and therefore should not underpin the Fund's assistance. ${ }^{6}$ From a political science perspective, Kapur and Naím (2005) argue that, whereas "the Fund generally plays a positive role" in middle-income countries, it is ill-suited for helping "small, structurally weak, low-income countries" (p. 100). They suggest that "other regional and international organizations" would be better placed to handle that task

Once one acknowledges that the boxes in which we tend to place countries analytically are arbitrary, debatable, and transitory (What is a "solvent emerging economy," and which countries fit this description?), the force of such arguments begins to fade. As an antidote, consider the more dynamic analysis of Kremer, Onatski, and Stock (2001), which provides an illustration and a tentative explanation for why countries cannot be treated as permanent members of a class. ${ }^{7}$ Building on a model developed by Quah (1993), they estimate long-run probabilities that poor or rich countries will become middle-income, or conversely. They find that a fall from richness is rare, but that countries do move between being poor and middle-income with greater frequency. Their suggested explanation for this stylized fact is that governments tend to experiment with various economic policy regimes until they find one that works. They continue to experiment until the cost of regime switching exceeds the expected growth and other benefits. Countries that reach the highest rungs of the distribution are unlikely to switch further and thus are likely to remain where they are. Less successful countries continue to experiment and thus might either rise or fall in the short run, but most should rise in the long run as better policy regimes are adopted.

A stark implication of this methodology is that the number of middle-income countries is likely to rise quite sharply over the next few decades, assuming that poor countries are able to learn from the experience of their more successful forerunners. Instead of the nearly 80 countries that are classified as low-income today, there could be as few as

\footnotetext{
${ }^{6}$ The Oxfam (2003) report was not arguing for less IMF lending, but rather for a less powerful "gatekeeper" role on the grounds that the IMF was allegedly preventing lowincome countries from obtaining sufficient aid from donors. For a review of these and other similar criticisms, see Bird and Mosley (2005).

${ }^{7}$ Thanks to Eduardo Borensztein for drawing attention to the implications of Kremer, Onatski, and Stock in this context.
} 
half that many two or three decades hence. ${ }^{8}$ The numbers of both middle-income and highincome countries would both rise, perhaps dramatically. Such an outcome is not inevitable, but the potential is there.

Looking back over the past two or three decades, it is not hard to find countries that have realized or at least begun to realize the potential to move up the ladder. Examples would include Botswana, Chile, China, Colombia, India, Korea, Turkey, and many once-poor fuel exporters such as Gabon, Libya, and Venezuela. Figure 3 illustrates the effect of this gradual progression on the IMF. For nearly the whole first decade of IMF operations (1947-55), the United States was the only creditor country. That monopoly ended when Canada qualified in 1956, and the next two decades saw a fairly steady rise as first Europe and Japan, then a few South American and other Asian countries, and finally the oil exporters of the Middle East joined the creditor ranks. The upheavals of the late 1970s and the 1980s brought a pause, but the globalization of the 1990s ushered in a new expansion of financial soundness and prosperity. At the end of 2004, the IMF had 45 creditor countries, including Chile and Colombia in South America and Botswana and Libya in Africa (for a list, see IMF, 2004a, p. 72).

What underpins the IMF's role in this dynamic process is an understanding that (1) the purpose of the international financial system (of which the IMF is a key component) is to help countries develop and move up the ladder and (2) that all countries need to pursue sound macroeconomic policies in order to succeed economically. Moreover, sustaining sound macroeconomic policies is neither easy nor free of cost. These points are examined further in Section IV.

Even though the IMF does not and should not provide development finance, it does aim to contribute to the development process within its mandate, by providing temporary financing in support of countries' efforts to strengthen their policies and their balance of payments. Rather than specializing horizontally by providing assistance to a select crosssection of countries, the IMF specializes vertically by offering to help all countries that are trying to improve macroeconomic policymaking. This vertical specialization is the underlying rationale for the IMF as a universal financial institution.

\section{Financial Classification of Countries}

As a basis for analyzing the contribution that IMF financial assistance might make for various groups of countries, the usual distinctions based on income level are not very helpful. What distinguishes countries with regular, intermittent, or rare demands for official assistance is the strength and stability of their national or fiscal finances, not the level of their

\footnotetext{
${ }^{8}$ As of March 2005, a total of 78 low-income countries were eligible to borrow from the Poverty Reduction and Growth Facility (PRGF) of the IMF. For a current list, see: http://www.imf.org/external/np/exr/facts/prgf.htm.
} 


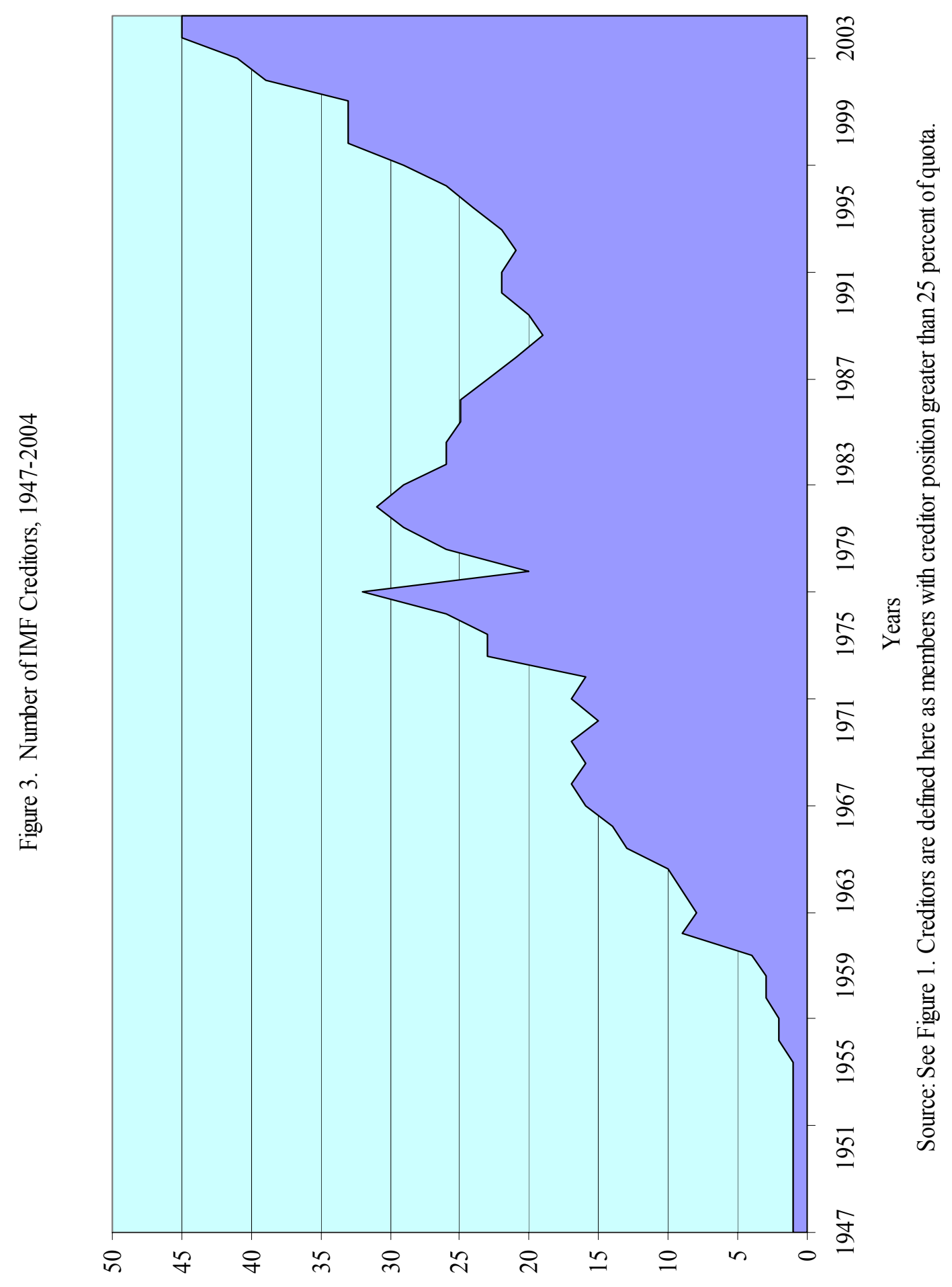


per capita incomes. The correlation between the two is certainly positive, but it is far from perfect. An alternative taxonomy based on financial strength may be more informative.

In this scheme, the first group of countries includes those that have adequate domestic saving, supplemented by a steady, reliable access to private international capital markets, and usually with an ability to borrow in their own currencies with little or no premium for default or exchange risk. These advanced financial economies are very unlikely to face a need for IMF financing, although a marked deterioration in conditions could push them out of this box (as happened to Korea in 1997). This group currently would include most of the 30 members of the OECD and a scattering of other countries, but the membership at the margins is fairly unstable. South Africa, for example, has been more successful at borrowing abroad in its own currency than have OECD members Korea and Mexico. Sweden is far behind Australia in the portion of its public external debt denominated in its own currency (Hausmann, Panizza, and Stein, 2000). Saudi Arabia and some other major oil exporters presumably could borrow in their own currencies with little premium if they chose to do so, regardless of their level of industrialization or economic development.

The second category comprises the emerging market economies. These countries have a substantial ability to mobilize domestic savings and to supplement them with private international capital, both in debt instruments and in equity claims, but their access to international capital is not assured. These countries may face a significant credit risk premium and are unlikely to borrow in their own currency: the source of the "original sin" concept introduced to the finance literature by Eichengreen and Hausmann (1999). Access to international capital is thus both expensive and unreliable, which makes these countries good candidates as applicants for occasional and intermittent financial assistance from the IMF.

Membership in the emerging-market group is inherently indefinite, especially around the margins. If it is defined broadly as comprising those countries that are neither advanced nor pre-emergent (as explained below), it probably includes close to 70 countries today. ${ }^{9}$ At the top end, the ambiguity of the status of Korea and Mexico has been discussed above. Quite a few other countries, including those that were admitted to EU membership in 2004, have begun to establish strong financial track records, and a number of those have been IMF creditors for at least the past few years. Many others clearly have emerging rather than

\footnotetext{
${ }^{9}$ To define a narrow set of emerging market economies, Klingen, Weder, and Zettelmeyer (2004) use a list of 27 developing countries for which secondary markets existed for their sovereign debt for all or part of the period 1986-2001. IMF (2003), Chapter 3, uses a similar definition but derives a somewhat more inclusive list (34 countries) based on more recent data. If countries with significant inflows of foreign direct investment (FDI) are also included, the list expands significantly. For example, Basu and Srinivasan (2002) discuss seven sub-Saharan African countries that have inward FDI flows but not significant portfolio flows. Finally, for purposes of this analysis, it is appropriate to include those countries that have strong enough economies that they have borrowed from the Fund, if at all, only occasionally and intermittently.
} 
advanced financial markets, but the bottom end is also fuzzy and unstable. In the 1970s, international banks were eagerly lending to Somalia, Sudan, and other low-income countries that today rely entirely on assistance from multilateral agencies and bilateral donors. ${ }^{10}$ Since the early 1990s, Honduras, Nicaragua, and Papua New Guinea have experienced economic deteriorations severe enough to qualify them for loans on concessional terms from the IMF. ${ }^{11}$ On the positive side, many once-poor countries - Botswana, China, the Dominican Republic, Egypt, and the Philippines, to name just a few-have graduated from reliance on official concessional assistance and are either in or close to the emerging market group. ${ }^{12}$ Others, though still having quite low per-capita incomes, have also gained some access to FDI or other private capital inflows. In sub-Saharan Africa, that group has recently included The Gambia and Senegal, and others, such as Uganda and Zambia, have had intermittent success in this regard.

The third category includes the rest of the world: the countries that we might call pre-emergent market economies. These countries - which could be low- or middle-income and would include many of the countries that are still in transition from centrally controlled to market economies - have little or no access to private-sector international capital. They also generally have insufficient domestic savings to finance the capital investment and social services that are prerequisites for economic growth. Even if capital were available, many governments of pre-emergent economies cannot afford to take on unsubsidized debt, so they are almost entirely dependent on official development assistance and concessional borrowing from multilateral creditors. In terms of the number of countries, this third group is the most numerous (perhaps 80 or so), but - as noted above - countries do slide between this category and the emerging market group.

\section{The Modern Role OF THE IMF}

If the IMF is to be a universal institution, how can it best serve the needs of each of these three groups of countries? To answer this question, it is essential to keep in mind that the purpose of the institution - indeed, the purpose of the international financial system - is not just to help countries avoid and deal with mishaps, to help them run in place without

\footnotetext{
${ }^{10}$ For these and other case studies, see Boughton (2001), Chapters 14 and 16.

${ }^{11}$ Honduras and Papua New Guinea were eligible for concessional loans in 1976-78 under the terms of the IMF Trust Fund, but none of these three countries was included in the initial list of eligible countries when the IMF resumed concessional lending in 1986. Honduras and Nicaragua were added in 1992, and Papua New Guinea was added in 2003.

${ }^{12}$ Botswana was eligible for IMF concessional loans in the 1970s but not subsequently. The Dominican Republic and the Philippines were removed from the list of eligible countries in 1995. China and Egypt graduated in 2000.
} 
stumbling. The purpose, at least for the latter two groups, is to help them grow. Over time, pre-emergent economies should emerge, and emerging markets should mature.

The main challenge facing most pre-emergent countries is development: economic, social, and institutional development. Among other challenges, these countries need better health systems, especially in the age of HIV/AIDS. According to the World Health Organization, the least-developed countries spend an average of \$US13 per person per year on health, a sum that cannot possibly begin to reduce their enormous deficiencies in access to health care. (See UNDP, 2003, Chapter 5.) Pre-emergent countries also need better education systems: more and better schools, more and better teachers, more pencils and books, better transportation systems for getting children to schools, more awareness of the value of educating girls as much as boys. At the same time, they need better access to clean water and sanitation facilities and better protection of the natural environment. Many of them need to diversify production so as to reduce dependence on one or two export commodities, but they need to diversify in ways that are consistent with their resource endowments and comparative advantages, and they need greater access to world markets. These are serious challenges that override and dominate the stabilization challenges on which the IMF famously focuses.

To meet these challenges, pre-emergent countries need more and better external support, predominantly in the form of reliable and effectively directed grants and highly concessional and long-term finance from donors. Because the IMF does not have, and cannot provide, that type of support, it is tempting to conclude that the institution is of little value for this group of countries. ${ }^{13}$ But pre-emergent countries also need to implement better policies, both for their own sake and to qualify for and attract development finance from donors. In that regard, in general terms, they need to improve their institutional structures, their systems of governance, their ability to raise tax revenues and control government spending, and - not least - their macroeconomic policies: fiscal, monetary, and exchange rate policies.

Several of these key targets for policy reform are within the IMF's mandate and field of expertise: macroeconomic policies, economic and financial governance, tax reform, and improved expenditure management. The IMF can help countries to make and adhere to policy commitments in these areas, and it can signal to donors that countries are making progress and are serious about reform. The financial role of the IMF is to commit enough money for a limited, but sufficient time to enable a country to undertake reforms without endangering financial stability, and enough to ensure that the accompanying policy advice and conditionality will be taken seriously by both sides. Although this role might lead to a continuing indebtedness to the IMF over a period of several years in cases where an ongoing relationship is beneficial to the country, the amounts will normally be quite small in relation to the country's overall development needs. The temporary nature of the financing, its

${ }^{13}$ The PRGF provides concessional loans to low-income countries, but it is a relatively small revolving fund, not a permanent source of development finance. The IMF also provides debt relief to eligible countries through its participation in the Heavily Indebted Poor Countries (HIPC) Initiative. 
dependence on macroeconomic policy reforms, and its limited size are the key components that distinguish the IMF's role from that of official development banks. ${ }^{14}$

For emerging market economies, the overarching challenge is to develop an economic and financial strength comparable to that of the more advanced countries. In contrast to preemergent countries, where IMF financing is expected to be small but possibly of some persistence, here IMF financing is expected to be intermittent and quickly repaid, but possibly quite large. Korea provides a good illustration of a country that began as a preemergent borrower and was indebted continuously from 1974 to 1987, and then developed into a country that needed the IMF only as an emergency backup in 1997-2000.

Whereas the effectiveness of the Fund's role in pre-emergent economies depends on its ability to encourage and induce policy improvements and to catalyze support from other official creditors and donors, the effectiveness of lending to emerging market economies depends largely on the country's ability to restore stability quickly and on the ability of the process to restore market confidence and thus catalyze inflows from private capital markets.

For the advanced economies, there is a strong expectation - but no guarantee - that they will never have to borrow from the IMF. Nonetheless, the IMF's charter gives every member country the right to borrow under specified conditions to meet a balance of payments need. The IMF recognizes this right by maintaining a prudential balance of usable resources equal to 20 percent of the quotas of its creditor countries (as defined above; and see Treasurer's Department, 2001). Although most of these countries never will borrow, a few of them may. In any event, the existence of the IMF as a standby lender is an integral part of its contribution to global financial stability.

What links these various financial roles together is the policy advice that the IMF proffers regularly to all members, whether they are active borrowers, strong creditors, or in between. Because that advice always focuses primarily on the policy requirements for achieving and maintaining macroeconomic and financial stability, its elements include some recurring and dominant themes. What varies more is the context. Consider the following examples relating to fiscal policy, which are drawn from recent staff reports on an advanced economy, an emerging market, and a pre-emergent country:

- $\quad$ For the United States: "The challenge [is] to sustain expenditure discipline, contain budgetary pressures, ... and anticipate costs of likely [tax] reform. ... Continuing the pace of deficit reduction beyond the next two years will help place the long-run fiscal position on a sustainable basis." (IMF, 2004c, p. 34)

\footnotetext{
${ }^{14}$ In practice, because Fund-supported programs in low-income countries usually include a broad array of structural as well as macroeconomic policy reforms, the signaling role of IMF support may be diluted as programs are suspended despite adequate progress on macroeconomic policies. Effectiveness requires that signals are clear and are not distorted by political pressures.
} 
- $\quad$ For Uruguay: "Staff commends the authorities' commitment to maintain expenditure restraint, keep public utility tariffs broadly aligned with operating costs, and refrain from any further tax reductions. Delivering on these commitments will be essential to maintain market confidence and meet the medium-term fiscal consolidation goals, as there is little scope for fiscal slippage." (IMF, 2004d, p. 21)

- $\quad$ For Uganda: "There is ... a pressing need to strengthen budget execution and the quality of government spending, and achieve a more sustainable external debt position. ... Although overall fiscal deficit targets have been met, persistent resort to supplementary appropriations has led to government spending outcomes that deviate from budget intentions, thus weakening the effectiveness of the budget as a development tool." (IMF, 2004b, p. 20)

While it is important for all countries to take such advice, the reasons differ. For preemergent markets such as Uganda's, macroeconomic stability has to be formulated in the context of - and in support of - a longer-run strategy aimed at achieving key development goals. Otherwise, conflicts will arise between development and stability (for example, cutting spending on health and education services could help reduce a fiscal deficit, but at the expense of the country's development goals), and stability will be squeezed out as the lower priority. Hence, in the passages quoted above, while fiscal consolidation is a featured goal in all three cases, ${ }^{15}$ advice to Uganda focuses squarely on optimizing the budget "as a development tool." For the emerging-market country, Uruguay, the advice is aimed at maintaining market confidence. For the advanced economy, the United States, the advice is aimed at putting the federal budget on a course that can be sustained over the longer term, thus avoiding the need for a belated and disruptive policy reversal.

How realistic is this approach? Getting the words right is one achievement, and generating real economic progress is another. For a practical answer to this question, it is necessary first to acknowledge two obvious but not innocuous points. First, there is no ideal international financial system, simply because we do not live in an ideal world. The current system has flaws and weaknesses, as do all the alternatives that have been or might be proposed. Second, no agency can solve or even marginally alleviate all of the economic and financial problems in the world: development and stabilization, for all types of countries. Specialization is essential and inevitable.

Some multilateral agencies specialize horizontally, by country type: the OECD (rich countries), the IBRD (middle-income), or IDA (low-income). While this horizontal specialization has the advantage of enabling a holistic approach to the agencies' policy advice, no institution can be expected to address the full range of problems that a country-

${ }^{15}$ The choice of these examples does not imply that the IMF always advises countries to tighten fiscal policy. The Independent Evaluation Office (2003) concluded, on the basis of a detailed study, that the "evidence does not support the view that IMF-supported programs adopt a one-size-fits all approach to fiscal adjustment ... [nor] the perception that programs always involve austerity by targeting reductions in ... fiscal deficits or in public expenditure" (p. 4). 
especially the least developed - might face. Moreover, as this paper has argued, allowance must be made for the tendency of countries to shift between categories. Alternatively, agencies can specialize vertically, by the type of problem, and stand ready to help any country that faces that type of problem. That is the logic behind the IMF.

Vertical specialization, however, has its own limitations. In particular, it requires a sophisticated understanding of the context in which policy advice and policy conditions are formulated. It also requires effective collaboration, both with the affected countries and with other specialized agencies. The IMF cannot help pre-emergent countries unless it embeds its advice in a broader development strategy. That, in turn, requires working with the country to ensure that a solid strategy is in place, and it requires working with multilateral development banks and donor countries in support of that strategy.

The Monterrey Consensus (United Nations, 2002) now provides such a framework. All countries that have not already achieved all of their development objectives are urged to specify quantitative and time-bound goals (notably, to cut extreme poverty in half between 1990 and 2015), set out a realistic strategy and tactics for reaching those goals, and carry out the necessary institutional and policy reforms. Developed countries have a responsibility to ensure that the global economy is conducive to development and to provide the necessary financial and other support to developing countries. And international agencies have a responsibility to work together and with national governments to provide additional support, advice, and coordination (IMF and World Bank, 2004).

\section{Concluding Thoughts}

The aim of this paper has been to set out an integrated framework for thinking about the constructive assistance that the IMF can provide to its member countries across the full spectrum of financial development. To be effective, that assistance must be not only well designed and well implemented but also accepted as a legitimate contribution to the general welfare. When conflicts arise between the interests of creditor and debtor countries, a transparent and fair system for resolving those differences is essential. In particular, if a permanent group of creditors were to take effective control without there being an appropriate counterbalance from the influence of the rest of the world community, the institution would be bound to lose credibility, to the detriment of both creditors and debtors. To minimize that danger, the system of governance of the institution should be adjusted periodically to reflect the evolution of the world economy.

The dynamic nature of the world economy, through which countries develop at different rates and shift_ — or at least know that they might shift_-between providing and using the financial resources of the IMF, has, in the past, helped to ensure a measure of balance in the institution's governance. Maintaining and strengthening that balance is a key challenge in preserving the future value of the IMF as a universal financial institution. As more and more countries advance to the point where they stop viewing themselves as potential borrowers, and as others borrow continuously for long periods and lose sight of the possibility of graduating from this dependence, the dangers of polarization of the membership and marginalization of the influence of borrowers become increasingly acute. 
At the deepest level, the vision set out in this paper requires good governance of the international financial system. As Pauly (1994) has reminded us, it requires "a deep sense that a global community exists" and "a vision of human solidarity" (p. 212). If an international agency imposes, or is perceived as imposing, the will of the powerful upon the weak, the benefits of universalism will be sadly diminished. 


\section{References}

Basu, Anupam, and Krishna Srinivasan, 2002, "Foreign Direct Investment in Africa-Some Case Studies," IMF Working Paper WP/02/61 (March). Available at http://www.imf.org/external/pubs/ft/wp/2002/wp0261.pdf.

Bird, Graham, and Paul Mosley, 2005, "Should the IMF Discontinue Its Lending Role in Low-Income Countries?", in Gustav Ranis and James Vreeland (editors), Globalization and the Nation State: The Impact of the IMF and the World Bank (forthcoming).

Boughton, James M., 2001. Silent Revolution: The International Monetary Fund 1979-1989. Washington: International Monetary Fund. Available at http://www.imf.org/external/pubs/ft/history/2001/index.htm.

Eichengreen, Barry, and Ricardo Hausmann (1999), "Exchange Rates and Financial Fragility," paper presented at the Federal Reserve Bank of Kansas City Conference, Issues in Monetary Policy, 27-29 August, Jackson Hole, Wyoming.

Fischer, Stanley, 2001, "Farewell to the IMF Executive Board" (August 30). Available at http://www.imf.org/external/np/speeches/2001/083001.htm.

Hausmann, Ricardo, Ugo Panizza, and Ernesto Stein, 2000, "Why Do Countries Float the Way They Float?", Inter-American Development Bank, Research Department Working Paper \#418 (May). Available at http://www.iadb.org/res/publications/pubfiles/pubWP418.pdf.

Independent Evaluation Office, 2003. Fiscal Adjustment in IMF-Supported Programs. Washington: International Monetary Fund. Available at http://www.imf.org/External/NP/ieo/2003/fis/index.htm.

International Monetary Fund, 2003. World Economic Outlook September 2003: Public Debt in Emerging Markets. Washington: International Monetary Fund. Available at http://www.imf.org/external/pubs/ft/weo/2003/02/index.htm.

,2004a. Annual Report 2004. Available at http://www.imf.org/external/pubs/ft/ar/2004/eng/index.htm.

,2004b. Uganda: Third Review Under the Three-Year Arrangement Under the Poverty Reduction and Growth Facility and Request for Waiver of Performance Criteria-Staff Report, IMF Country Report No. 04/289 (September 2004).

Washington: International Monetary Fund. Available at http://www.imf.org/external/pubs/ft/scr/2004/cr04289.pdf.

,2004c. United States: 2004 Article IV Consultation-Staff Report, IMF Country Report No. 04/34 (July 2004). Washington: International Monetary Fund. Available at http://www.imf.org/external/pubs/ft/scr/2004/cr04230.pdf.

, 2004d. Uruguay: Fifth Review Under the Stand-By Arrangement and Requests for Modification of the Arrangement and Waiver of Nonobservance and Applicability of Performance Criteria-Staff Report, IMF Country Report No. 04/327 (October 2004). Washington: International Monetary Fund. Available at http://www.imf.org/external/pubs/ft/scr/2004/cr04327.pdf. 
International Monetary Fund and World Bank, 2004. Global Monitoring Report 2004:

Policies and Actions for Achieving the Millennium Development Goals and Related

Outcomes. Washington: World Bank. Available at

http://siteresources.worldbank.org/globalmonitoringext/Resources/0821358596.pdf.

Kapur, Devesh, and Moisés Naím, 2005, “The IMF and Democratic Governance," Journal of Democracy, Vol. 16, No. 1 (January), pp. 89-102.

Klingen, Christoph, Beatrice Weder, and Jeromin Zettelmeyer, 2004, "How Private Creditors Fared in Emerging Debt Markets, 1970-2000," IMF Working Paper WP/04/13.

Washington: International Monetary Fund. Available at http://www.imf.org/external/pubs/ft/wp/2004/wp0413.pdf.

Kremer, Michael, Alexei Onatski, and James Stock, 2001, "Searching for Prosperity," NBER Working Paper 8250. Cambridge, Massachusetts: National Bureau of Economic Research. Available at http://www.nber.org/papers/w8250.

Meltzer, Allan H. (Chairman), 2000. Report of the International Financial Institutions Advisory Commission (Meltzer Commission). Available at http://www.house.gov/jec/imf/ifiac.htm.

Oxfam International, 2003. The IMF and the Millennium Goals: Failing to Deliver for LowIncome Countries. Oxfam Briefing Paper 54, September 2003. Available at http://www.oxfam.org/eng/pdfs/pp030917_imf_mdgs.pdf.

Pauly, Louis W., 1994, "Promoting a Global Economy: The Normative Role of the International Monetary Fund," in Richard Stubbs and Geoffrey R. D. Underhill (Editors), Political Economy and the Changing Global Order. Toronto: McClelland \& Stewart, Inc.

Quah, Danny, 1993, “Empirical Cross-Section Dynamics in Economic Growth,” European Economic Review, Vol. 37, pp. 426-34.

Treasurer's Department, International Monetary Fund, 2001. Financial Organization and Operations of the IMF. Pamphlet No. 45, Sixth Edition. Available at http://www.imf.org/external/pubs/ft/pam/pam45/contents.htm.

United Nations, 2002. Report of the International Conference on Financing for Development, Monterrey, Mexico, 18-22 March 2002. A/Conf.198/11. Available at http://www.un.org/esa/ffd/.

United Nations Development Programme, 2003. Human Development Report 2003. New York and Oxford: Oxford University Press. Available at http://hdr.undp.org/reports/global/2003/.

World Bank, 2004. Annual Report. Table on country eligibility for borrowing is available at http://www.worldbank.org/annualreport/2004/Vol_2/PDF/WB percent20Annual percent 20Report percent202004.pdf. 